\title{
Air quality and radiative forcing impacts of anthropogenic volatile organic compound emissions from ten world regions
}

\author{
M. M. Fry ${ }^{1, *}$, M. D. Schwarzkopf ${ }^{2}$, Z. Adelman ${ }^{1}$, and J. J. West ${ }^{1}$ \\ ${ }^{1}$ Department of Environmental Sciences and Engineering, University of North Carolina at Chapel Hill, Chapel Hill, North \\ Carolina, USA \\ ${ }^{2}$ NOAA Geophysical Fluid Dynamics Laboratory, Princeton, New Jersey, USA \\ *now at: US Environmental Protection Agency, Washington, DC, USA
}

Correspondence to: J. J. West (jjwest@email.unc.edu)

Received: 21 May 2013 - Published in Atmos. Chem. Phys. Discuss.: 13 August 2013

Revised: 27 November 2013 - Accepted: 5 December 2013 - Published: 16 January 2014

\begin{abstract}
Non-methane volatile organic compounds (NMVOCs) influence air quality and global climate change through their effects on secondary air pollutants and climate forcers. Here we simulate the air quality and radiative forcing (RF) impacts of changes in ozone, methane, and sulfate from halving anthropogenic NMVOC emissions globally and from 10 regions individually, using a global chemical transport model and a standalone radiative transfer model. Halving global NMVOC emissions decreases global annual average tropospheric methane and ozone by $36.6 \mathrm{ppbv}$ and $3.3 \mathrm{Tg}$, respectively, and surface ozone by $0.67 \mathrm{ppbv}$. All regional reductions slow the production of peroxyacetyl nitrate (PAN), resulting in regional to intercontinental PAN decreases and regional $\mathrm{NO}_{\mathrm{x}}$ increases. These $\mathrm{NO}_{\mathrm{x}}$ increases drive tropospheric ozone increases nearby or downwind of source regions in the Southern Hemisphere (South America, Southeast Asia, Africa, and Australia). Some regions' NMVOC emissions contribute importantly to air pollution in other regions, such as East Asia, the Middle East, and Europe, whose impact on US surface ozone is $43 \%, 34 \%$, and $34 \%$ of North America's impact. Global and regional NMVOC reductions produce widespread negative net RFs (cooling) across both hemispheres from tropospheric ozone and methane decreases, and regional warming and cooling from changes in tropospheric ozone and sulfate (via several oxidation pathways). The $100 \mathrm{yr}$ and $20 \mathrm{yr}$ global warming potentials $\left(\mathrm{GWP}_{100}, \mathrm{GWP}_{20}\right)$ are 2.36 and 5.83 for the global reduction, and 0.079 to 6.05 and -1.13 to 18.9 among the 10 regions. The NMVOC RF and GWP estimates are generally lower than previously modeled estimates, due to the greater
\end{abstract}

$\mathrm{NMVOC} / \mathrm{NO}_{\mathrm{x}}$ emissions ratios simulated, which result in less sensitivity to NMVOC emissions changes and smaller global $\mathrm{O}_{3}$ burden responses, in addition to differences in the representation of NMVOCs and oxidation chemistry among models. Accounting for a fuller set of RF contributions may change the relative magnitude of each region's impacts. The large variability in the RF and GWP of NMVOCs among regions suggest that regionally specific metrics may be necessary to include NMVOCs in multi-gas climate trading schemes.

\section{Introduction}

Non-methane volatile organic compounds (NMVOCs) are chemically reactive gases emitted worldwide from natural and anthropogenic sources. NMVOCs impact air quality and climate by contributing to tropospheric photochemistry (e.g., ozone $\left(\mathrm{O}_{3}\right)$ production) and aerosol formation. Because of their influence on short-lived climate forcers (e.g., $\mathrm{O}_{3}$, methane $\left(\mathrm{CH}_{4}\right)$, aerosols), NMVOC reductions could help slow the near-term rate of climate change (Shindell et al., 2012). Here we evaluate the net climate and air quality effects of anthropogenic NMVOC emission reductions, to inform future policies that may address air quality and climate change.

Tropospheric $\mathrm{CH}_{4}$ and $\mathrm{O}_{3}$ are the largest greenhouse gas contributors to global anthropogenic radiative climate forcing $(\mathrm{RF})$ behind carbon dioxide $\left(\mathrm{CO}_{2}\right)$ with abundance-based RFs of $0.48 \pm 0.05 \mathrm{~W} \mathrm{~m}^{-2}$ and $0.35(-0.1,+0.3) \mathrm{W} \mathrm{m}^{-2}$, 
respectively (Forster et al., 2007). Tropospheric sulfate $\left(\mathrm{SO}_{4}^{2-}\right)$ has produced a global net $\mathrm{RF}$ of $-0.40 \pm 0.2 \mathrm{~W} \mathrm{~m}^{-2}$ (direct effect only) (Forster et al., 2007). NMVOCs and carbon monoxide (CO) emissions together have contributed an estimated global mean $\mathrm{RF}$ of $0.21 \pm 0.10 \mathrm{~W} \mathrm{~m}^{-2}$ due to $\mathrm{O}_{3}$ and $\mathrm{CH}_{4}$ (1750 to 1998) (Shindell et al., 2005; Forster et al., 2007) and $0.25 \pm 0.04 \mathrm{~W} \mathrm{~m}^{-2}$ (1750 to 2000) when $\mathrm{SO}_{4}^{2-}$, nitrate $\left(\mathrm{NO}_{3}^{-}\right)$, and $\mathrm{CO}_{2}$ impacts are included (Shindell et al., 2009). More recently, the anthropogenic RF of NMVOC emissions (for 1850-2000) was estimated as $0.090 \mathrm{~W} \mathrm{~m}^{-2}$ (due to changes in $\mathrm{O}_{3}, \mathrm{CH}_{4}$, and $\mathrm{CO}_{2}$ ) as part of the Atmospheric Chemistry and Climate Model Intercomparison Project (ACCMIP) (Stevenson et al., 2013).

NMVOCs are oxidized by the hydroxyl radical $(\mathrm{OH})$ in the troposphere, producing peroxyl radicals $\left(\mathrm{RO}_{2}\right)$ and hydroperoxy radicals $\left(\mathrm{HO}_{2}\right)$ that then oxidize nitric oxide (NO) to yield $\mathrm{O}_{3}$. Other reactants (e.g., $\mathrm{O}_{3}$ and $\mathrm{NO}_{3}$ radicals) also contribute to oxidation reactions. Because thousands of NMVOC species with varying lifetimes (from fractions of a day to months) and chemical reactivities have been documented, global chemical transport models (CTMs) use simplified representations of NMVOCs and reaction pathways (Ehhalt et al., 2001; Prather et al., 2001; Ito et al., 2007). Under high nitrogen oxide $\left(\mathrm{NO}_{\mathrm{x}}=\mathrm{NO}+\mathrm{NO}_{2}\right)$ concentrations, NMVOCs contribute to the efficient cycling between $\mathrm{OH}$ and $\mathrm{HO}_{2}$ and hence, $\mathrm{O}_{3}$ production, while under low- $\mathrm{NO}_{\mathrm{x}}$ conditions $\mathrm{OH}$ depletes, resulting in NMVOC and methane $\left(\mathrm{CH}_{4}\right)$ accumulation (Collins et al., 2002). $\mathrm{CH}_{4}$ is a longer-lived $\mathrm{O}_{3}$ precursor (perturbation lifetime of $\sim 12 \mathrm{yr}$ ) (Forster et al., 2007) that decreases as tropospheric OH increases (from NMVOC reductions), resulting in long-term $\mathrm{O}_{3}$ decreases, in addition to direct, short-term $\mathrm{O}_{3}$ decreases (Prather et al., 1996; Wild et al., 2001; Fiore et al., 2002; Naik et al., 2005). NMVOC emissions also affect $\mathrm{O}_{3}$ at local to intercontinental scales, given that the lifetimes of tropospheric $\mathrm{O}_{3}(\sim 22$ days) (Stevenson et al., 2006) and some NMVOCs (e.g., ethane, benzene) can exceed typical intercontinental transport times (5 to 10 days) (Fiore et al., 2009; West et al., 2009a). NMVOC reductions indirectly influence sulfate aerosol $\left(\mathrm{SO}_{4}^{2-}\right)$ formation via gas-phase oxidation of sulfur dioxide $\left(\mathrm{SO}_{2}\right)$ by $\mathrm{OH}$, and aqueous-phase oxidation of $\mathrm{SO}_{2}$ by $\mathrm{H}_{2} \mathrm{O}_{2}$ or $\mathrm{O}_{3}$ (Unger et al., 2006; Leibensperger et al., 2011). NMVOCs are also precursors to secondary organic aerosols (SOA), and influence $\mathrm{NO}_{3}^{-}$aerosol abundance via oxidant changes (Ehhalt et al., 2001; Bauer et al., 2007; Hoyle et al., 2009).

Previous studies have shown that the RF and global warming potential (GWP) of NMVOCs, like other short-lived $\mathrm{O}_{3}$ precursors, depend on emissions location given their short lifetime in the troposphere (Naik et al., 2005; Berntsen et al., 2006; Forster et al., 2007; Fry et al., 2012), but few studies quantify the range among different source regions. Fry et al. (2012) calculated $100 \mathrm{yr}$ and $20 \mathrm{yr}$ GWPs $\left(\mathrm{GWP}_{100}, \mathrm{GWP}_{20}\right)$ of $4.8 \pm 2.4$ to $8.3 \pm 1.9$ and $15.5 \pm 6.8$ to $26.5 \pm 5.3$, respectively, for anthropogenic NMVOCs from four regions (due to $\mathrm{O}_{3}, \mathrm{CH}_{4}$, and $\mathrm{SO}_{4}^{2-}$ ) using an ensemble of models. Collins et al. (2002) also presented GWP 100 estimates of 1.8 to 5.5 ( -50 to $+100 \%$ uncertainty) due to $\mathrm{CH}_{4}$ and $\mathrm{O}_{3}$, but for individual anthropogenic NMVOCs globally.

Using global models of chemical transport and radiative transfer, we simulate the air quality and net RF impacts, via changes in $\mathrm{O}_{3}, \mathrm{CH}_{4}$, and $\mathrm{SO}_{4}^{2-}$, of halving all anthropogenic NMVOC emissions together, globally and from 10 regions, as was done for CO emissions by Fry et al. (2013). We evaluate the sensitivity of air quality and RF to NMVOC emission location, and the corresponding NMVOC GWPs, which may support the inclusion of NMVOCs in multi-gas emission trading schemes for climate. We do not consider reductions in co-emitted species that would be affected by measures to reduce NMVOCs. Future studies could evaluate the impacts of measures on multiple species, or combine the results presented here with those for co-emitted species to determine the net effect of emission control measures (Shindell et al., 2012).

\section{Methods}

\subsection{Global chemical transport model}

We evaluate the impacts on surface air quality and tropospheric composition of halving anthropogenic NMVOC emissions globally and from 10 regions (North America (NA), South America (SA), Europe (EU), the former Soviet Union (FSU), Southern Africa (AF), India (IN), East Asia (EA), Southeast Asia (SE), Australia and New Zealand (AU), and the Middle East and Northern Africa (ME)) (Fig. S1) (Fry et al., 2013). We use the global chemical transport model (CTM), Model for OZone And Related chemical Tracers version 4 (MOZART-4) (Emmons et al., 2010).

The base and $\mathrm{CH}_{4}$ control (where global $\mathrm{CH}_{4}$ was reduced by $20 \%$ ) simulations are documented in a previous study in which the base simulation was shown to generally agree with surface and tropospheric observations (Fry et al., 2013). Here we simulate new perturbation experiments that reduce regional and global anthropogenic NMVOC emissions by $50 \%$ for 1 July 2004 through 31 December 2005 using MOZART4 at a horizontal resolution of $1.9^{\circ}$ latitude $\times 2.5^{\circ}$ longitude with 56 vertical levels. We use the Coupled Model Intercomparison Project phase 5 (CMIP5) Representative Concentration Pathway 8.5 (RCP8.5) emissions inventory for the year 2005 (Riahi et al., 2007, 2011) and global meteorology from the Goddard Earth Observing System Model, version 5 (GEOS-5) (2004 to 2006) (Rienecker et al., 2008). Anthropogenic emissions include all anthropogenic sectors except biomass burning emissions (Fig. S2), which are excluded since actions to address biomass burning (i.e., reductions in burning) differ from the other anthropogenic sectors (Naik et al., 2007), and would likely reduce the emissions of 
all co-emitted species by similar percentages. Actions to reduce anthropogenic emissions from industrial sources, on the other hand, likely have differing effects on NMVOCs relative to other co-emitted species.

RCP8.5 NMVOC species are re-speciated to MOZART4 NMVOC categories, and monthly temporal variation is added to all anthropogenic species and source categories, except for shipping, aircraft, and biomass burning, which already have monthly temporal variation (Fig. S2, Table S1). The Model of Emissions of Gases and Aerosols from Nature (MEGAN) (Guenther et al., 2006) within MOZART-4 calculates the biogenic emissions of isoprene and monoterpenes $\left(\mathrm{C}_{10} \mathrm{H}_{16}\right)$ (global annual totals of $738 \mathrm{Tg} \mathrm{C} \mathrm{yr}^{-1}$ and $107 \mathrm{Tg} \mathrm{C} \mathrm{yr}^{-1}$, respectively), while all other natural emissions are from Emmons et al. (2010) (Table S2). The global annual lightning $\mathrm{NO}_{\mathrm{x}}$ and soil $\mathrm{NO}_{\mathrm{x}}$ emissions are also calculated by MOZART-4 as $2.4 \mathrm{Tg} \mathrm{N} \mathrm{yr}^{-1}$ and $8.0 \mathrm{Tg} \mathrm{N} \mathrm{yr}^{-1}$ (Fry et al., 2013).

Because the perturbation simulations are only $1.5 \mathrm{yr}$ in length, we account for the influence of NMVOC emissions on $\mathrm{CH}_{4}$ (via $\mathrm{OH}$ ), and thus long-term changes in $\mathrm{O}_{3}$ on the decadal timescale of the $\mathrm{CH}_{4}$ perturbation lifetime, using methods from previous studies (Prather et al., 2001; West et al., 2007; Fiore et al., 2009; Fry et al., 2012). Global $\mathrm{CH}_{4}$ is set to a uniform mixing ratio of 1783 parts per billion by volume (ppbv) (WMO, 2006) in the base and perturbation simulations. The $\mathrm{CH}_{4}$ control simulation reduced global $\mathrm{CH}_{4}$ to $1426.4 \mathrm{ppbv}$. The results from the base and $\mathrm{CH}_{4}$ control simulations were used by Fry et al. (2013) to estimate $\mathrm{CH}_{4}$ lifetime against loss by tropospheric $\mathrm{OH}\left(\tau_{\mathrm{OH}}\right.$, $11.24 \mathrm{yr}$ ), total $\mathrm{CH}_{4}$ lifetime based on $\tau_{\mathrm{OH}}$ and $\mathrm{CH}_{4}$ loss to soils and the stratosphere ( $\left.\tau_{\text {total }}, 9.66 \mathrm{yr}\right)$, and methane's feedback factor (F, 1.29) by the methods of Prather et al. (2001) and Stevenson et al. (2013). We use these parameters to estimate the steady-state tropospheric $\mathrm{CH}_{4}$ change for each of the NMVOC perturbations. Long-term $\mathrm{O}_{3}$ responses are then calculated offline by scaling $\mathrm{O}_{3}$ changes from the $\mathrm{CH}_{4}$ control simulation by the ratio of the global $\mathrm{CH}_{4}$ change from each perturbation to that of the $\mathrm{CH}_{4}$ control. We add longterm $\mathrm{O}_{3}$ changes to direct short-term $\mathrm{O}_{3}$ changes to estimate the net change at steady state (West et al., 2007, 2009b; Fiore et al., 2009; Fry et al., 2012).

Since MOZART-4 does not have complete stratospheric chemistry (Emmons et al., 2010), we merge each simulation's steady-state (short-term + long-term) tropospheric $\mathrm{O}_{3}$ distributions (in three dimensions) with the monthly mean stratospheric $\mathrm{O}_{3}$ concentrations from the AC\&C/SPARC (Stratospheric Processes And their Role in Climate) $\mathrm{O}_{3}$ database prepared for CMIP5 (Available: http://pcmdi-cmip. llnl.gov/cmip5/forcing.html) (Cionni et al., 2011). By omitting lower stratospheric $\mathrm{O}_{3}$ changes between each perturbation and the base simulation, our RF estimates likely underestimate the full effect of NMVOC emissions (Søvde et al., 2011).
MOZART-4 accounts for the tropospheric aerosols $\mathrm{SO}_{4}^{2-}$, black carbon (BC), primary and secondary organics, $\mathrm{NO}_{3}^{-}$, dust, and sea salt aerosols (Lamarque et al., 2005). Here we focus on changes in $\mathrm{SO}_{4}^{2-}, \mathrm{NO}_{3}^{-}$, and $\mathrm{SOA}$, as these species are most directly influenced by anthropogenic NMVOCs, where NMVOCs are precursors to SOA, and changes in oxidants affect all three aerosol species (Barth et al., 2000; Metzger et al., 2002; Chung and Seinfeld, 2002).

\subsection{Radiative transfer model}

We use the NOAA Geophysical Fluid Dynamics Laboratory (GFDL) standalone radiative transfer model (RTM) to perform stratospheric-adjusted net RF calculations (Schwarzkopf and Ramaswamy, 1999; GFDL GAMDT, 2004; Naik et al., 2005, 2007) as in Fry et al. (2012), with the same updates to long-lived greenhouse gases (Meinshausen et al., 2011) and solar forcing (http://www.geo.fu-berlin.de/en/met/ag/strat/forschung/ SOLARIS/Input_data/CMIP5_solar_irradiance.html) from Fry et al. (2013). Net RF is calculated as the difference between the perturbed and base cases' simulated monthly mean net radiation fluxes (net shortwave minus net longwave), in each grid cell and month, at the tropopause after stratospheric temperatures have readjusted to radiative equilibrium (Naik et al., 2007; Saikawa et al., 2009; Fry et al., 2012). We quantify the net RF from changes in tropospheric steady-state $\mathrm{O}_{3}, \mathrm{CH}_{4}$, and $\mathrm{SO}_{4}^{2-}$ (direct effect only), as modeled by the MOZART-4 simulations. Meteorological fields from GFDL's atmosphere model (AM2) and land model (LM2), sampled one day per month at midmonth for the year 2005, are also used as input to the RTM simulations, representing monthly mean conditions (Naik et al., 2005).

The RTM currently does not calculate the RF of SOA and $\mathrm{NO}_{3}^{-}$aerosols. We also do not account for the $\mathrm{RF}$ of changes in stratospheric $\mathrm{O}_{3}$, water vapor, the carbon cycle (via $\mathrm{O}_{3}$ and nitrogen deposition, affecting plants), and $\mathrm{CO}_{2}$ (via NMVOC oxidation, which has a minor influence on the net RF of NMVOCs) (Shindell et al., 2009). We do not estimate $\mathrm{CO}_{2}$ forcing here, because this carbon is likely accounted for in $\mathrm{CO}_{2}$ inventories (Daniel and Solomon, 1998). Our RTM simulations also exclude the indirect effects of aerosols on clouds and the internal mixing of aerosols, where aerosol indirect effects are highly uncertain and may account for considerable RF beyond aerosol direct effects (Forster et al., 2007; Shindell et al., 2013).

\section{Tropospheric composition and surface air quality}

\subsection{Methane and ozone}

Global annual average changes in steady-state tropospheric $\mathrm{CH}_{4}$ abundance, calculated from the tropospheric $\mathrm{CH}_{4}$ loss flux diagnosed from the model (West et al., 2007; Fiore et al., 2009; Fry et al., 2013), are largest for ME ( -7.37 ppbv) 


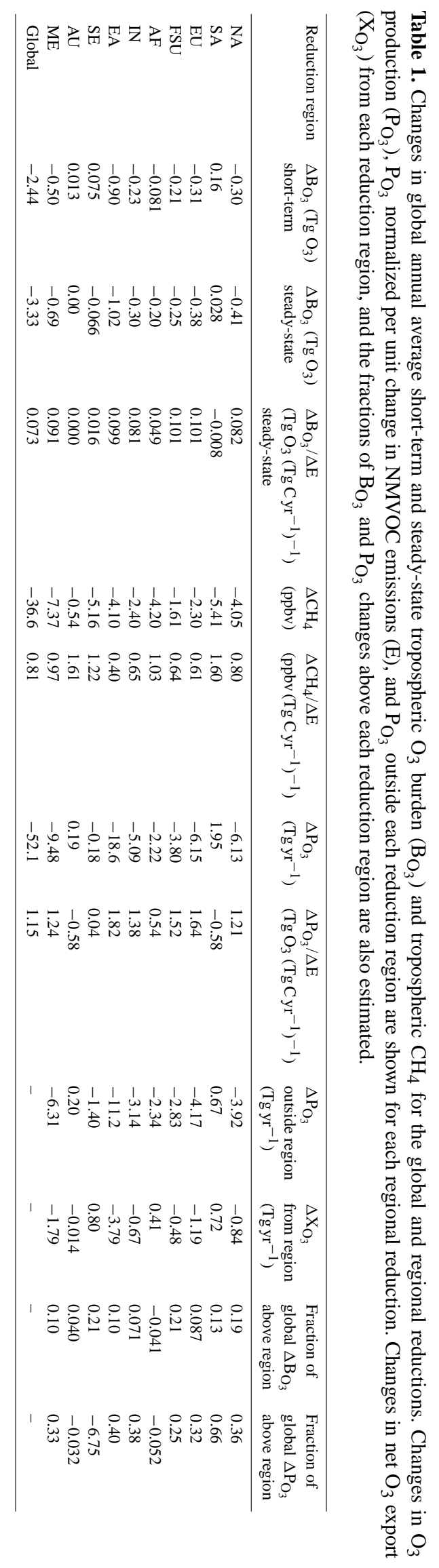


Table 2. For the global and regional reduction simulations relative to the base, global annual average changes in short-term and steadystate surface $\mathrm{O}_{3}$.

\begin{tabular}{lll}
\hline $\begin{array}{l}\text { Reduction } \\
\text { region }\end{array}$ & $\begin{array}{l}\Delta \text { Surface } \mathrm{O}_{3} \\
\text { short term (pptv) }\end{array}$ & $\begin{array}{l}\Delta \text { Surface } \mathrm{O}_{3} \\
\text { steady state (pptv) }\end{array}$ \\
\hline NA & -81.0 & -89.9 \\
SA & -1.40 & -13.3 \\
EU & -87.5 & -92.6 \\
FSU & -71.0 & -74.5 \\
AF & -18.2 & -27.5 \\
IN & -28.9 & -34.2 \\
EA & -167.1 & -176.2 \\
SE & -9.40 & -20.8 \\
AU & 0.60 & -0.60 \\
ME & -100.6 & -116.8 \\
Global & -592.9 & -673.5 \\
\hline
\end{tabular}

and SA ( $-5.41 \mathrm{ppbv})$ reductions among the 10 regions (Table 1). Normalized global $\mathrm{CH}_{4}$ changes range from 0.40 to

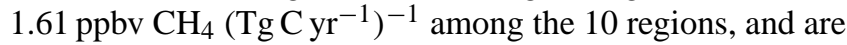
most sensitive to reductions from AU, SA, SE, and AF. These are regions of low $\mathrm{NO}_{\mathrm{x}}$, as discussed below, where reducing NMVOCs lessens $\mathrm{OH}$ depletion, creating greater global $\mathrm{CH}_{4}$ changes per unit emission. $\mathrm{CH}_{4}$ decreases are least sensitive to NMVOC reductions from high- $\mathrm{NO}_{\mathrm{x}}$ regions (EA, EU, FSU). Naik et al. (2005) also found greater global $\mathrm{CH}_{4}$ sensitivities for $\mathrm{NO}_{\mathrm{x}}$ emissions from low- $\mathrm{NO}_{\mathrm{x}}$ regions (SE, $\mathrm{SA}$, and $\mathrm{AU}$ ), and lower sensitivities for high- $\mathrm{NO}_{\mathrm{x}}$ regions (EU, FSU).

Global short-term and steady-state surface $\mathrm{O}_{3}$ changes for the 10 regional reductions are nearly proportional to NMVOC emissions changes $\left(R^{2}=0.69\right.$ and 0.81) (Fig. S3), but not as strongly correlated as for regional $\mathrm{CO}$ reductions (Fry et al., 2013). NMVOC emissions produce long-term $\mathrm{O}_{3}$ decreases that augment short-term decreases by $13 \%$ for the global reduction, and by $5-18 \%$ for the regional reductions (Fig. 1, Table 2), similar to Fiore et al. (2009) and West et al. (2007). SA, AF, and SE reductions provide more substantial long-term global surface $\mathrm{O}_{3}$ changes, which account for $\sim 34$ to $89 \%$ of steady-state $\mathrm{O}_{3}$ decreases.

Several of the regional reductions (SA, AF, SE, and AU) in the tropics and Southern Hemisphere $(\mathrm{SH})$ produce regional to intercontinental tropospheric $\mathrm{O}_{3}$ column increases (Fig. 2), as the sensitivity of $\mathrm{O}_{3}$ to NMVOC emissions varies by world region. All of the regional reductions slow the formation of peroxyacetyl nitrate (PAN), causing PAN to decrease regionally to hemispherically and $\mathrm{NO}_{\mathrm{x}}$ to increase regionally (Figs. S5, S6, and S7). For SA, AF, SE, and $\mathrm{AU}$, these $\mathrm{NO}_{\mathrm{x}}$ increases cause $\mathrm{O}_{3}$ column increases near or downwind of the region. For the other regions, decreases in NMVOCs decrease $\mathrm{O}_{3}$, outweighing the influence of $\mathrm{NO}_{\mathrm{x}}$ increases via slowing PAN production. Whether NMVOC reductions cause $\mathrm{O}_{3}$ to increase or decrease de-

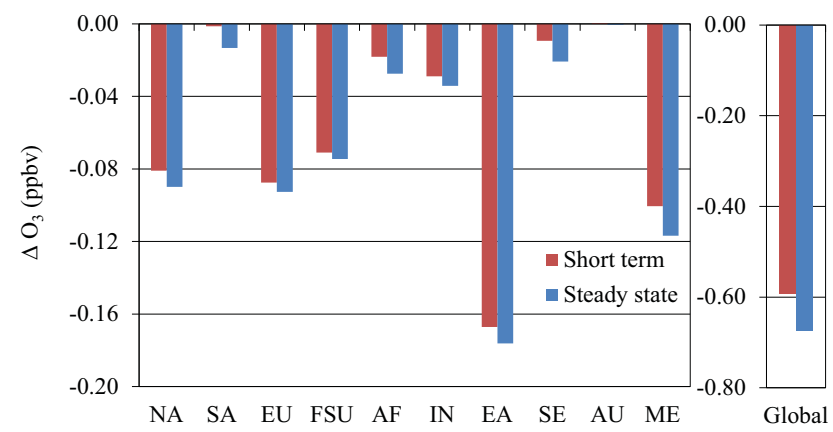

Fig. 1. Global annual average surface $\mathrm{O}_{3}$ concentration changes (ppbv) for the regional and global reduction simulations, in the short term and at steady state.

pends on the regional chemical state. Here $\mathrm{O}_{3}-\mathrm{NO}_{\mathrm{x}}-\mathrm{VOC}$ sensitivity is analyzed using the photochemical indicator ratios: $\mathrm{P}\left(\mathrm{H}_{2} \mathrm{O}_{2}\right) / \mathrm{P}\left(\mathrm{HNO}_{3}\right.$, where $\mathrm{P}()$ refers to production rate, $\left(\mathrm{H}_{2} \mathrm{O}_{2}\right) /\left(\mathrm{HNO}_{3}\right)$, and $\left(\mathrm{H}_{2} \mathrm{O}_{2}\right) /\left(\mathrm{NO}_{2}\right)$ (Sillman et al., 1997; Liu et al., 2010). The modeled indicator ratios show that $\mathrm{NO}_{\mathrm{x}}$-sensitive conditions prevail in the tropics and southern midlatitudes, supporting the finding of tropospheric $\mathrm{O}_{3}$ increases from SA, AF, SE, and AU reductions (Figs. S8, S9, and S10). The northern mid- to high latitudes more frequently exhibit VOC sensitivity (weaker $\mathrm{NO}_{\mathrm{x}}$ sensitivity), particularly from November to March, resulting in $\mathrm{O}_{3}$ decreases.

The global distributions of steady-state surface and tropospheric $\mathrm{O}_{3}$ show the greatest decreases within each reduction region, and smaller decreases intercontinentally (Figs. 2, S4, and Table S3). Although the largest changes in surface $\mathrm{O}_{3}$ occur within the hemisphere of reduction, given that interhemispheric transport takes $\sim 1$ year (Jacob, 1999), more widespread decreases reflect global long-term $\mathrm{O}_{3}$ decreases (via $\mathrm{CH}_{4}$ decreases). NMVOC reductions in one region can also influence surface $\mathrm{O}_{3}$ concentrations in other regions importantly (Tables S3 and S4). In fact, the EA, ME, and EU NMVOC reductions have an impact on US surface $\mathrm{O}_{3}$ that is $43 \%, 34 \%$, and $34 \%$, respectively, of that from the NA reduction. Two of the low- $\mathrm{NO}_{\mathrm{x}}$ regions (SA and $\mathrm{SE}$ ) experience greater decreases in surface $\mathrm{O}_{3}$ from foreign regions' NMVOCs than domestic NMVOCs.

The global annual average steady-state tropospheric $\mathrm{O}_{3}$ burden decreases by $0.073 \mathrm{Tg} \mathrm{O}_{3}\left(\mathrm{Tg} \mathrm{Cyr}^{-1}\right)^{-1}$ for the global reduction and by -0.008 to $0.101 \mathrm{Tg} \mathrm{O}_{3}$ $\left(\mathrm{Tg} \mathrm{Cyr}^{-1}\right)^{-1}$ for the 10 regions (Table 1). Changes in $\mathrm{O}_{3}$ production $(\Delta \mathrm{P})$ and export $(\Delta \mathrm{X})$ are also calculated to determine the importance of long-range transport of $\mathrm{O}_{3}$ and its precursors. For most regions, changes in $\mathrm{O}_{3}$ production outside of each reduction region exceed changes in $\mathrm{O}_{3}$ export from each region, suggesting that the influence of NMVOC emissions on the downwind production of $\mathrm{O}_{3}$ has a greater impact on long-range $\mathrm{O}_{3}$ than the formation and export of $\mathrm{O}_{3}$ from each region (Table 1). In contrast, for the $\mathrm{SA}, \mathrm{AF}$, and 

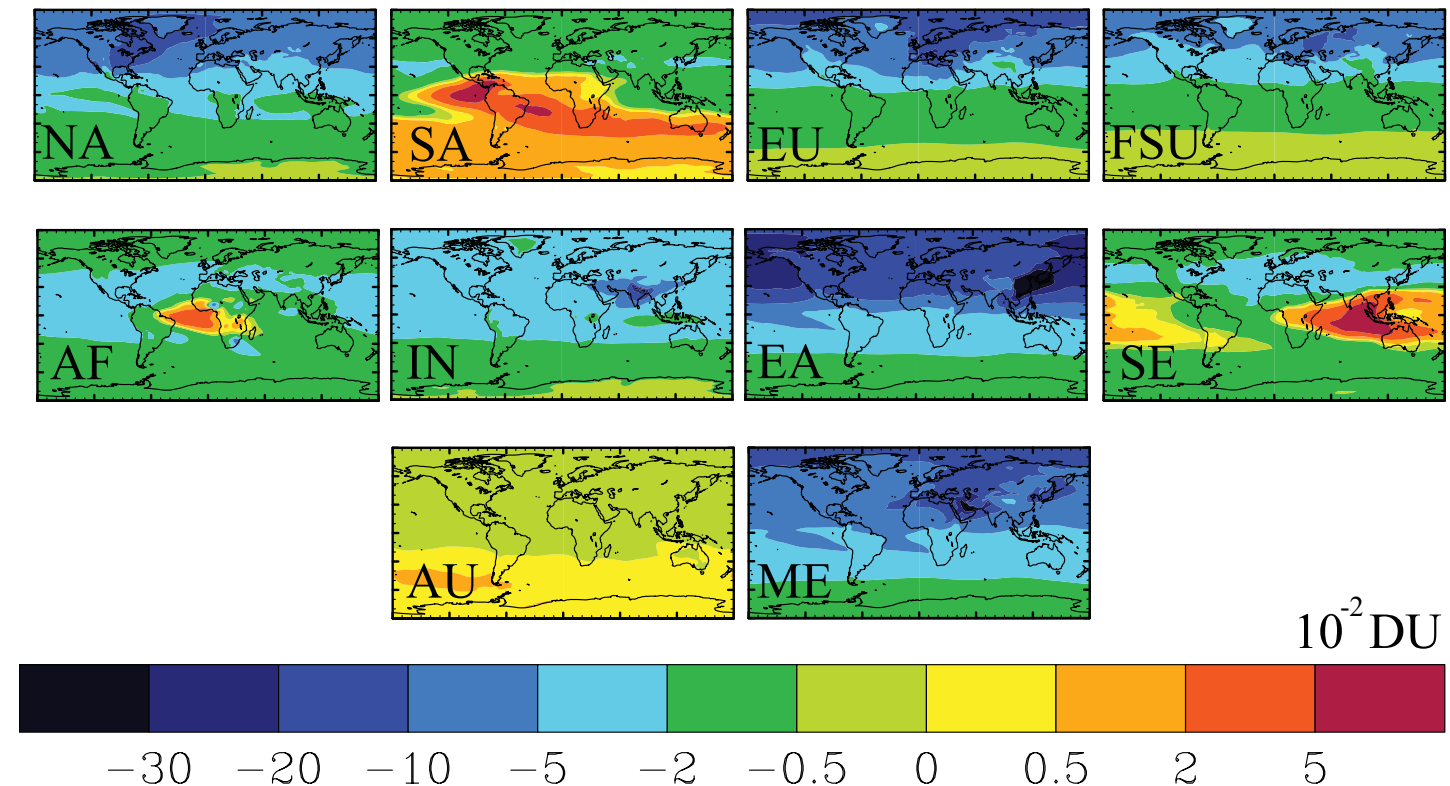

Fig. 2. Global distribution of annual average changes in tropospheric total column $\mathrm{O}_{3}$ at steady state $\left(1 \times 10^{-2} \mathrm{DU}\right)$ for each of the regional reduction simulations relative to the base.
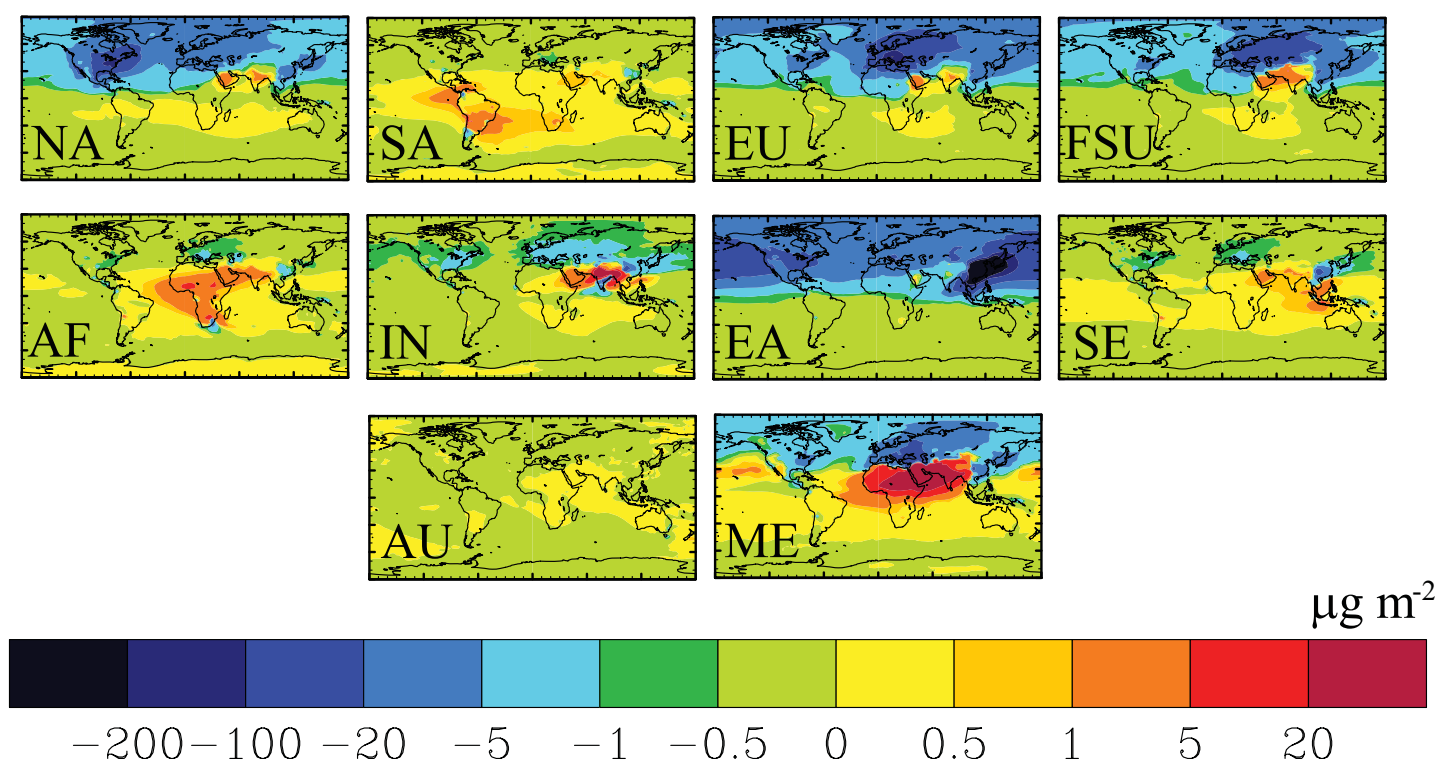

Fig. 3. Global distribution of annual average changes in tropospheric total column $\mathrm{SO}_{4}^{2-}\left(\mu \mathrm{g} \mathrm{m}{ }^{-2}\right)$ for each of the regional reduction simulations relative to the base.

SE reductions, $\Delta \mathrm{X}$ is positive due to regional $\mathrm{O}_{3}$ increases. $\mathrm{O}_{3}$ production outside the reduction region decreases for $\mathrm{AF}$ and SE, yet increases for SA, as SA causes widespread increases in tropospheric $\mathrm{O}_{3}$ (Fig. 2). For AU, regional tropospheric $\mathrm{O}_{3}$ export decreases, while tropospheric $\mathrm{O}_{3}$ production increases outside AU (Table 1, Fig. 2).

\subsection{Aerosols}

NMVOC reductions affect the oxidation of $\mathrm{SO}_{2}, \mathrm{NO}_{\mathrm{x}}$, monoterpenes, and toluene, influencing tropospheric $\mathrm{SO}_{4}^{2-}$, $\mathrm{NO}_{3}^{-}$, and SOA concentrations. Reductions from regions near the Equator and in drier areas (SA, AF, IN, SE, and ME) produce widespread $\mathrm{SO}_{4}^{2-}$ increases (Fig. 3), related to increased gas-phase $\mathrm{SO}_{2}$ oxidation by $\mathrm{OH}$. In fact, most of the regional reductions, except $\mathrm{EA}$ and $\mathrm{AU}$, produce localized increases in $\mathrm{SO}_{4}^{2-}$ over drier areas (e.g., the Middle East and 
Table 3. For the global and regional reduction simulations relative to the base, global annual average tropospheric burden changes in $\mathrm{SO}_{4}^{2-}, \mathrm{NO}_{3}^{-}$(expressed as $\mathrm{NH}_{4} \mathrm{NO}_{3}$ ), and SOA. The global annual average tropospheric $\mathrm{SO}_{4}^{2-}, \mathrm{NH}_{4} \mathrm{NO}_{3}$, and $\mathrm{SOA}$ burdens in the base simulation are $1785 \mathrm{Gg} \mathrm{SO}_{4}^{2-}, 416 \mathrm{Gg} \mathrm{NH}_{4} \mathrm{NO}_{3}$, and $227 \mathrm{Gg}$ SOA.

\begin{tabular}{lrcr}
\hline $\begin{array}{l}\text { Reduction } \\
\text { region }\end{array}$ & $\begin{array}{r}\Delta \mathrm{SO}_{4}^{2-} \\
(\mathrm{Gg})\end{array}$ & $\begin{array}{r}\Delta \mathrm{NH}_{4} \mathrm{NO}_{3} \\
(\mathrm{Gg})\end{array}$ & $\begin{array}{r}\Delta \mathrm{SOA} \\
(\mathrm{Gg})\end{array}$ \\
\hline $\mathrm{NA}$ & -1.63 & 0.61 & -2.91 \\
$\mathrm{SA}$ & 0.05 & 0.17 & -4.57 \\
$\mathrm{EU}$ & -2.26 & 1.47 & -1.30 \\
$\mathrm{FSU}$ & -1.45 & 0.88 & -0.74 \\
$\mathrm{AF}$ & 0.06 & 0.21 & -2.84 \\
$\mathrm{IN}$ & -0.03 & 0.05 & -1.66 \\
$\mathrm{EA}$ & -10.3 & 3.21 & -3.69 \\
$\mathrm{SE}$ & -0.06 & 0.38 & -5.00 \\
$\mathrm{AU}$ & -0.01 & 0.01 & -0.25 \\
$\mathrm{ME}$ & 1.63 & 0.09 & -1.89 \\
$\mathrm{Global}$ & -14.8 & 7.27 & -24.9 \\
\hline
\end{tabular}

India). Tropospheric $\mathrm{O}_{3}$ increases from the $\mathrm{SA}, \mathrm{AF}$, and $\mathrm{SE}$ reductions also contribute to $\mathrm{SO}_{4}^{2-}$ increases via enhanced aqueous-phase $\mathrm{SO}_{2}$ oxidation by $\mathrm{O}_{3}$, where aqueous-phase $\mathrm{SO}_{2}$ oxidation is more efficient than gas-phase oxidation (Unger et al., 2006). Regional reductions in the northern midlatitudes (NA, EU, FSU, and EA) result in widespread decreases in $\mathrm{SO}_{4}^{2-}$, due to the prevalence of clouds and decreased aqueous-phase oxidation (in clouds) of $\mathrm{SO}_{2}$ by $\mathrm{O}_{3}$ and $\mathrm{H}_{2} \mathrm{O}_{2}$ (Figures 3, $\mathrm{S} 11$, and $\mathrm{S} 12$ ). $\mathrm{NO}_{3}^{-}$changes include both regional increases and decreases. As with $\mathrm{SO}_{4}^{2-}, \mathrm{NO}_{3}^{-}$ increases are expected due to $\mathrm{OH}$ increases that are global in scale, yet largest over the source region (Figures S13 and S14). SOA decreases globally, influenced not only by oxidant changes, but also by NMVOCs directly, as NMVOCs are precursors to SOA. The largest SOA decreases occur over the reduction region (Fig. S15). While MOZART-4 accounts for SOA formation through the oxidation of monoterpenes and toluene, more research is needed to more fully model SOA. Current models greatly simplify the physical and chemical processes contributing to SOA burden, and underpredict SOA formation compared to observations (Carlton et al., 2009).

Global annual average $\mathrm{SO}_{4}^{2-}$ burden decreases for most regional reductions, yet increases for $\mathrm{SA}, \mathrm{AF}$, and $\mathrm{ME}$ (Table 3). For all 10 regional reductions, global $\mathrm{NO}_{3}^{-}$burden increases and global SOA burden decreases. The sums of global burden changes for all 10 regional reductions, for $\mathrm{SO}_{4}^{2-}, \mathrm{NO}_{3}^{-}$, and $\mathrm{SOA}$, are 95 to $99 \%$ of the burden changes for the global NMVOC reduction, suggesting some dependence on regional conditions and chemistry.

Summing the effects of individual aerosol species shows that the greatest changes in fine particulate matter $\left(\mathrm{PM}_{2.5}\right.$, estimated as a sum not including dust and sea salt) occur within the reduction region, and extend intercontinentally in some cases (Fig. S16). Halving global NMVOC emissions slightly decreases global and regional annual average surface $\mathrm{PM}_{2.5}$ concentrations (Table S7). Regional NMVOC reductions also have a small influence on surface $\mathrm{PM}_{2.5}$ concentrations in other regions (Table S8, S9), but halving NMVOCs generally does not have a strong influence on $\mathrm{PM}_{2.5}$ air quality, with changes smaller than the accuracy of the model and measurements.

\section{Radiative forcing and global warming potential}

The global annual average net $\mathrm{RF}$ is estimated as $-9.73 \mathrm{~mW} \mathrm{~m}^{-2}$ for the global $50 \%$ NMVOC reduction or $0.21 \mathrm{~mW} \mathrm{~m}^{-2}\left(\mathrm{TgC} \mathrm{yr}^{-1}\right)^{-1}$ (Table 4). This estimate for the global NMVOC reduction differs somewhat from the sum of the 10 regions' global net RF estimates $\left(12.5 \mathrm{~mW} \mathrm{~m}^{-2}\right)$ (Table 4), suggesting some level of error in adding the ten regions' net RF impacts to get a global total net RF. However, in order to compare with other estimates of anthropogenic forcing, we estimate the global net RF by multiplying each region's global net RF per unit emissions (Table 4) by total anthropogenic emissions including biomass burning, which were excluded in the $50 \%$ reductions (Table S2). We then sum the ten regions' global net RF estimates to yield $0.0374 \mathrm{~W} \mathrm{~m}^{-2}$ as the net RF of anthropogenic NMVOCs.

This approach accounts for the geographic variability of biomass burning emissions, yet assumes the same mixture of NMVOC species as anthropogenic emissions. The influence of climate change from the preindustrial to the present day is also omitted, as all simulations use 2005 meteorology. While this estimate of total net RF is derived using methods that differ from the ACCMIP and IPCC AR5 standard RF definitions, which are present day relative to the year 1850 and 1750, respectively, it provides an opportunity to compare with other studies. This RF is $\sim 66 \%$ of the ACCMIP multimodel mean global net RF of NMVOC emissions for 1850-2000 due to $\mathrm{O}_{3}$ and $\mathrm{CH}_{4}$ changes alone $\left(0.057 \mathrm{~W} \mathrm{~m}^{-2}\right)$ (Stevenson et al., 2013), and 15 to $18 \%$ of previous $\mathrm{CO}+\mathrm{NMVOC}$ RF estimates: $0.25 \pm 0.04 \mathrm{~W} \mathrm{~m}^{-2}$ (Shindell et al., 2009) and $0.21 \pm 0.1 \mathrm{~W} \mathrm{~m}^{-2}$ (Shindell et al., 2005; Forster et al., 2007). The RF of anthropogenic NMVOCs is $\sim 2.4 \%$ of global net RF of $\mathrm{CO}_{2}\left(1.56 \mathrm{~W} \mathrm{~m}^{-2}\right)$, and among the positive short-lived forcing agents $\left(\mathrm{CO}, \mathrm{CH}_{4}\right.$, NMVOCs, and BC), $2.4 \%$ of their total RF $\left(1.57 \mathrm{~W} \mathrm{~m}^{-2}\right)$ (Forster et al., 2007).

Across the 10 regions, the global annual average net $\mathrm{RF}$, normalized per unit change in NMVOC emissions, is $0.30 \pm 0.15 \mathrm{~mW} \mathrm{~m}^{-2}\left(\mathrm{Tg} \mathrm{C} \mathrm{yr}^{-1}\right)^{-1}$ (mean \pm 1 standard deviation), suggesting variability in the forcings due to different regions' emissions. The normalized RF is most sensitive to NMVOC emissions from regions in the tropics and $\mathrm{SH}$ (ME, $\mathrm{AU}, \mathrm{AF}$, and IN). Monthly global net RF estimates vary from 
Table 4. Annual net RF globally and by latitude band $\left(\mathrm{mW} \mathrm{m}^{-2}\right)$ and $\mathrm{GWP}_{20}$ and $\mathrm{GWP}_{100}$ estimates for the global and regional reduction simulations relative to the base, due to changes in tropospheric steady-state $\mathrm{O}_{3}, \mathrm{CH}_{4}$, and $\mathrm{SO}_{4}^{2-}$ concentrations. Global annual net $\mathrm{RF}$ per unit change in NMVOC emissions $\left(\mathrm{mW} \mathrm{m}^{-2}\left(\mathrm{Tg} \mathrm{C} \mathrm{yr}^{-1}\right)^{-1}\right)$ is also shown. The 10 regions estimate represents the sum of the net $\mathrm{RFs}$ from all 10 regional reductions; this estimate is not directly estimated by the RTM.

\begin{tabular}{|c|c|c|c|c|c|c|c|c|}
\hline $\begin{array}{l}\text { Reduction } \\
\text { region }\end{array}$ & $\begin{array}{l}\text { Global annual } \\
\text { net RF }\end{array}$ & $\begin{array}{l}\text { Global annual } \\
\text { net RF per } \\
\text { Tg NMVOC }\end{array}$ & $\begin{array}{l}\text { Annual net RF } \\
90^{\circ} \mathrm{S}-28^{\circ} \mathrm{S}\end{array}$ & $\begin{array}{l}\text { Annual net RF } \\
28^{\circ} \mathrm{S}-28^{\circ} \mathrm{N}\end{array}$ & $\begin{array}{l}\text { Annual net RF } \\
28^{\circ} \mathrm{N}-60^{\circ} \mathrm{N}\end{array}$ & $\begin{array}{l}\text { Annual net RF } \\
60^{\circ} \mathrm{N}-90^{\circ} \mathrm{N}\end{array}$ & $\mathrm{GWP}_{20}$ & $\mathrm{GWP}_{100}$ \\
\hline NA & -1.50 & 0.30 & -1.19 & -2.13 & -0.46 & -2.09 & 9.20 & 3.27 \\
\hline SA & -1.17 & 0.35 & -0.63 & -1.20 & -1.98 & -1.38 & 8.56 & 3.86 \\
\hline EU & -0.70 & 0.19 & -0.69 & -1.46 & 1.05 & -1.16 & 5.36 & 2.05 \\
\hline FSU & -0.51 & 0.20 & -0.48 & -1.05 & 0.58 & -0.71 & 5.96 & 2.24 \\
\hline $\mathrm{AF}$ & -1.56 & 0.38 & -1.24 & -1.99 & -1.79 & -1.17 & 11.8 & 4.19 \\
\hline IN & -1.38 & 0.37 & -0.83 & -2.12 & -1.54 & -0.96 & 12.7 & 4.08 \\
\hline EA & -0.05 & 0.0045 & -1.41 & -0.24 & 5.98 & -3.30 & -1.13 & 0.079 \\
\hline $\mathrm{SE}$ & -1.23 & 0.29 & -1.24 & -0.79 & -1.85 & -1.39 & 7.58 & 3.23 \\
\hline $\mathrm{AU}$ & -0.13 & 0.40 & 0.016 & -0.25 & -0.21 & -0.14 & 10.5 & 4.41 \\
\hline ME & -4.22 & 0.55 & -2.29 & -6.80 & -4.56 & -3.06 & 18.9 & 6.05 \\
\hline Global & -9.73 & 0.21 & -8.36 & -13.8 & -1.21 & -14.0 & 5.83 & 2.36 \\
\hline 10 regions & -12.5 & 0.28 & -9.98 & -18.0 & -4.77 & -15.3 & - & - \\
\hline
\end{tabular}

0.03 to 3.5 times the annual mean (excluding EA, which has even greater variability), with the greatest negative RFs from June to August (Fig. S17).

Regional reductions in NMVOC emissions cause widespread negative net RFs (cooling) across both hemispheres from decreases in global $\mathrm{CH}_{4}$ and long-term $\mathrm{O}_{3}$ (Fig. 4). Negative RFs over several source regions (e.g., IN, ME) result from short-term $\mathrm{O}_{3}$ decreases and regional $\mathrm{SO}_{4}^{2-}$ increases (Fig. 3). Regional positive RFs (warming) arise from regional $\mathrm{SO}_{4}^{2-}$ decreases (e.g., NA, EU, FSU, EA, and SE reductions) (Fig. 3), which can oppose the negative RFs of $\mathrm{O}_{3}$ decreases, and tropospheric $\mathrm{O}_{3}$ increases (e.g., SA, AF, SE, and AU reductions) (Fig. 2). These influences are supported by the distributions of changes in longwave radiation (Fig. S18), dominated by $\mathrm{O}_{3}$ and $\mathrm{CH}_{4}$ changes, and shortwave radiation (Fig. S19), dominated by $\mathrm{SO}_{4}^{2-}$. Since the RTM does not calculate the RF of SOA and $\mathrm{NO}_{3}^{-}$ aerosols presently, our simulated net RFs omit these forcing contributions. If changes in $\mathrm{SOA}$ and $\mathrm{NO}_{3}^{-}$were accounted for by the RTM, tropospheric SOA decreases (greater than $\mathrm{SO}_{4}^{2-}$ changes in some regions) would likely add small regional warming, while tropospheric $\mathrm{NO}_{3}^{-}$increases and decreases (mostly lesser than $\mathrm{SO}_{4}^{2-}$ changes) would add slight regional cooling and warming effects. Globally, $\mathrm{NO}_{3}^{-}$ and SOA would contribute small negative and positive RFs, respectively, to global net RF. Previous modeling studies have estimated $\mathrm{NO}_{3}^{-} \mathrm{RF}$ as $-0.06 \mathrm{~W} \mathrm{~m}^{-2}$ (Bauer et al., 2007) and SOA RF as -0.06 to $-0.09 \mathrm{~W} \mathrm{~m}^{-2}$ (Hoyle et al., 2009), for the present day relative to the preindustrial, both of which are small compared to greenhouse gas forcings like tropospheric $\mathrm{O}_{3}\left(0.41 \mathrm{~W} \mathrm{~m}^{-2}\right)$ (Stevenson et al., 2013).

Using the methods of Collins et al. (2013) and Fry et al. $(2012,2013)$, we calculate GWPs for each reduction as the RF integrated to 20 and $100 \mathrm{yr}$, normalized by the emissions change, and divided by the equivalent for $\mathrm{CO}_{2}(\mathrm{Ta}-$ ble 4). These GWPs represent short-term contributions from $\mathrm{SO}_{4}^{2-}$ and $\mathrm{O}_{3}$ (assumed constant over one year and zero thereafter), and long-term contributions of $\mathrm{CH}_{4}$ and $\mathrm{O}_{3}$ (responding and decaying with the $\mathrm{CH}_{4}$ perturbation lifetime of $12.48 \mathrm{yr}$ ) (Fry et al., 2013). The long-term $\mathrm{O}_{3} \mathrm{RF}$ component is calculated by scaling the $\mathrm{O}_{3} \mathrm{RF}$ from the $\mathrm{CH}_{4}$ control simulation by the ratio of the long-term $\mathrm{O}_{3}$ burden change from each perturbation to that of the $\mathrm{CH}_{4}$ control. Short-term $\mathrm{O}_{3}$ $\mathrm{RF}$ is the difference between steady-state $\mathrm{O}_{3} \mathrm{RF}$ (simulated by the RTM) and long-term $\mathrm{O}_{3}$ RF.

$\mathrm{GWP}_{20}$ and $\mathrm{GWP}_{100}$ are estimated as 5.83 and 2.36, respectively, for the global reduction, and -1.13 to 18.9 and 0.079 to 6.05 among the 10 regions, suggesting strong dependence on emission location, consistent with the normalized net RFs (Fig. 5). $\mathrm{GWP}_{20}$ and $\mathrm{GWP}_{100}$ are greatest for ME, which also had the largest net RF sensitivity, and smallest for EA, because of the nearly equivalent (opposing) short- and long-term effects. SA, SE, and AU reductions yield the largest (negative) short-term components for $\mathrm{GWP}_{20}$ and $\mathrm{GWP}_{100}$ due to the combined effect of $\mathrm{SO}_{4}^{2-}$ and tropospheric $\mathrm{O}_{3}$ increases, which act in the opposite direction to the long-term component. Uncertainty in NMVOC GWPs is based on the spread across an ensemble of global CTMs from Fry et al. (2012) ( \pm 1 standard deviation, $\mathrm{GWP}_{20}: \pm 6.0$ and $\left.\mathrm{GWP}_{100}: \pm 2.1\right)$, but do not account for the full uncertainty, as additional forcings could change net RF and GWP estimates. The signs of the total global net RF and GWPs are mostly positive, as they represent the overall warming effect of present-day anthropogenic NMVOCs compared to the preindustrial, in contrast to the negative global annual average net RFs (Table 4) due to reductions in NMVOC emissions. 

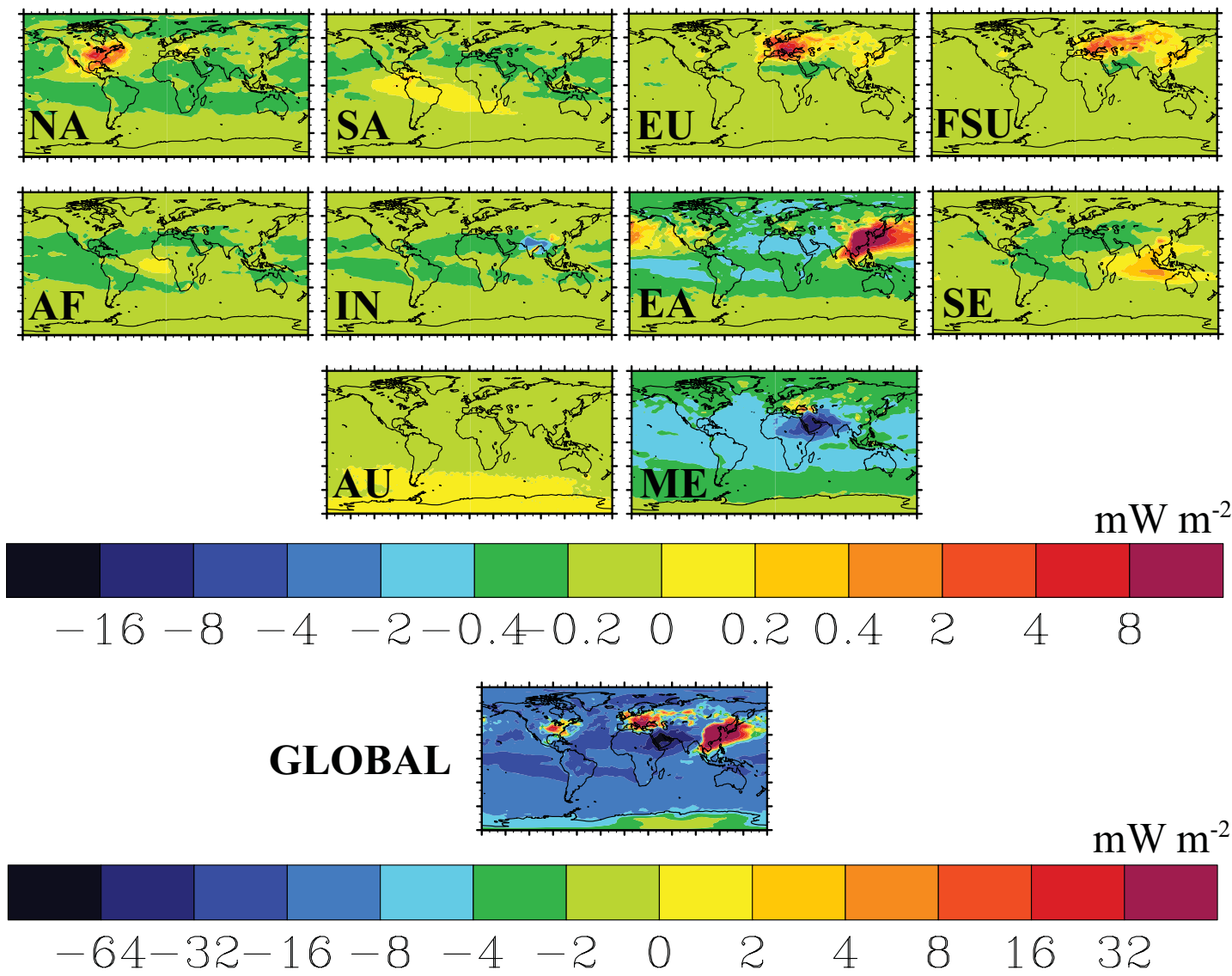

Fig. 4. Annual average net $\mathrm{RF}$ distributions $\left(\mathrm{mW} \mathrm{m}^{-2}\right)$ due to changes in tropospheric steady-state $\mathrm{O}_{3}, \mathrm{CH}_{4}$, and $\mathrm{SO}_{4}^{2-}$ for the regional and global NMVOC reduction simulations minus the base simulation.

Our GWPs (and RFs) do not include the forcing from $\mathrm{CO}_{2}$ as NMVOCs oxidize, since carbon emissions are often accounted for in $\mathrm{CO}_{2}$ inventories (Fuglestvedt et al., 1996; Daniel and Solomon, 1998; Collins et al., 2002). Including $\mathrm{CO}_{2}$ forcing, however, may provide a more complete accounting of the effects of NMVOCs, increasing each $\mathrm{GWP}_{20}$ and $\mathrm{GWP}_{100}$ estimate by $3.67\left(44 \mathrm{~g} \mathrm{CO}_{2} \mathrm{~mol}^{-1}\right.$ $\left(56.6 \mathrm{~g} \mathrm{C} \mathrm{mol}^{-1}\right)^{-1} \cdot 4.7 \mathrm{C}$ per NMVOC molecule), based on the global annual average molecular weight and number of carbons per molecule for anthropogenic NMVOC emissions. This increases the global $\mathrm{GWP}_{20}$ and $\mathrm{GWP}_{100}$ by $63 \%$ and $155 \%$, respectively, and makes all regional $\mathrm{GWP}_{20}$ and $\mathrm{GWP}_{100}$ estimates positive.

The $\mathrm{GWP}_{20}$ and $\mathrm{GWP}_{100}$ estimates for NA, EU, and IN (South Asia) reductions are approximately 32 to $41 \%, 61$ to $69 \%$, and 50 to $52 \%$ lower than the multimodel mean estimates of Fry et al. (2012) (Table S10). EA GWP 20 and $\mathrm{GWP}_{100}$ estimates, being near zero, also greatly contrast with Fry et al. (2012). Here total NMVOC/NO $\mathrm{NO}_{\mathrm{x}}$ emissions ratios are $57 \%$ greater globally and in NA than the multimodel mean ratios, partly due to greater biogenic NMVOC emissions (calculated online in MOZART-4) for the year 2005. The multimodel ensemble evaluated by Fry et al. (2012) uti- lizes an emissions inventory representative of the year 2001. In EU, EA, and IN, the total $\mathrm{NMVOC} / \mathrm{NO}_{\mathrm{x}}$ emissions are closer to the multimodel mean ratios: $4 \%$ and $9 \%$ (EU and EA, respectively) less and $8 \%$ (IN) greater than those of the multimodel mean (Table $\mathrm{S} 11$ ). Global $\mathrm{O}_{3}$ burden responses

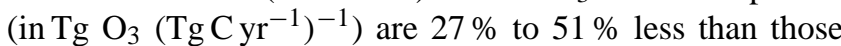
in Fry et al. (2012), likely due to the greater NMVOC/NO emission ratios in this study, which would suggest less sensitivity to NMVOC emissions, but differences in the representations of NMVOCs and oxidation chemistry among models may also contribute to these differences. Global $\mathrm{SO}_{4}^{2-}$ responses (in $\mathrm{Gg} \mathrm{SO}_{4}^{2-}\left(\mathrm{Tg} \mathrm{C} \mathrm{yr}^{-1}\right)^{-1}$ ) also highly vary, more commonly causing increases in $\mathrm{SO}_{4}^{2-}$ compared to the decreases in Fry et al. (2012) (Table S12). Collins et al. (2002) calculated $\mathrm{GWP}_{100}$ estimates for individual NMVOC species (due to $\mathrm{CH}_{4}$ and $\mathrm{O}_{3}$ only) ranging from 1.9 to 5.5 ( $-50 \%$ to $100 \%$ uncertainty), which are more similar to the GWP $\mathrm{GWO}_{100}$ magnitudes estimated here. While our NMVOC GWP estimates consider all anthropogenic NMVOCs together and are derived from only one CTM and RTM, they represent emissions from a greater number of regions, including the tropics and extra-tropics. 

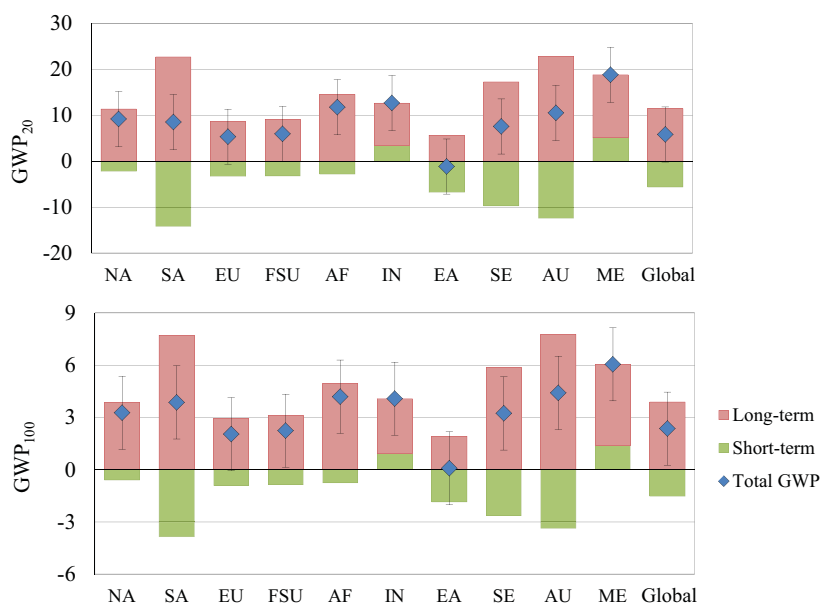

Fig. 5. Global warming potentials for NMVOCs at time horizons of 20 and $100 \mathrm{yr}\left(\mathrm{GWP}_{20}, \mathrm{GWP}_{100}\right)$ for the regional and global reductions, with contributions from short-term $\left(\mathrm{O}_{3}\right.$ and $\left.\mathrm{SO}_{4}^{2-}\right)$ and long-term $\left(\mathrm{O}_{3}\right.$ and $\left.\mathrm{CH}_{4}\right)$ components, where total GWP is shortterm + long-term. Uncertainty bars represent the average uncertainty found by Fry et al. (2012) based on the spread of atmospheric chemical models ( \pm 1 standard deviation).

\section{Summary}

Reducing NMVOC emissions provides regional to global benefits to air quality and climate. Halving anthropogenic NMVOCs from each region creates widespread small negative net RFs across both hemispheres from global $\mathrm{CH}_{4}$ and long-term $\mathrm{O}_{3}$ decreases. $\mathrm{RF}$ is also negative near several source regions (e.g., IN, ME) due to regional $\mathrm{SO}_{4}^{2-}$ increases and short-term $\mathrm{O}_{3}$ decreases. Regional small positive RFs correspond to regional $\mathrm{SO}_{4}^{2-}$ decreases (e.g., NA, EU, FSU, $\mathrm{EA}$, and $\mathrm{SE}$ ) and tropospheric $\mathrm{O}_{3}$ increases (e.g., SA, AF, $\mathrm{SE}$, and $\mathrm{AU})$.

The global annual average net RF for the global 50\% NMVOC reduction is estimated as $-9.73 \mathrm{~mW} \mathrm{~m}^{-2}$ or $0.21 \mathrm{~mW} \mathrm{~m}^{-2}\left(\mathrm{Tg} \mathrm{C} \mathrm{yr}^{-1}\right)^{-1}$. Our RF, GWP 20 , and GWP 100 estimates for the NA, EA, EU, and IN reductions are lower than the multimodel mean estimates of Fry et al. (2012), due to differences in $\mathrm{O}_{3}-\mathrm{NO}_{\mathrm{x}}-\mathrm{VOC}$ sensitivities and $\mathrm{SO}_{4}^{2-}$ responses, and in particular, because of regional $\mathrm{O}_{3}$ increases and $\mathrm{SO}_{4}^{2-}$ decreases for some regions that oppose the long-term cooling. Considerable variability in the global net RF, $\mathrm{GWP}_{20}$, and $\mathrm{GWP}_{100}$ estimates among regions suggests a strong dependence on emission location: $0.21 \mathrm{~mW} \mathrm{~m}^{-2}\left(\mathrm{Tg} \mathrm{C} \mathrm{yr}^{-1}\right)^{-1}, 5.83$, and 2.36 for the global reduction, and $0.30 \pm 0.15 \mathrm{~mW} \mathrm{~m}^{-2}\left(\mathrm{TgC} \mathrm{yr}^{-1}\right)^{-1},-1.13$ to 18.9 , and 0.079 to 6.05 for the 10 regions. $\mathrm{GWP}_{20}$ and $\mathrm{GWP}_{100}$ are greatest for regions in the tropics and SH (i.e., $\mathrm{ME}$, IN, and AF) and less for regions in the northern midlatitudes (i.e., EU and FSU). The lowest $\mathrm{GWP}_{20}$ and $\mathrm{GWP}_{100}$ estimates are for EA, given the nearly equivalent (opposing) short- and long-term effects. Including additional forc- ings beyond $\mathrm{CH}_{4}, \mathrm{O}_{3}$, and $\mathrm{SO}_{4}^{2-}$ would likely change $\mathrm{RF}$ and GWP estimates.

Variability in global annual average tropospheric $\mathrm{CH}_{4}$, $\mathrm{O}_{3}$, and $\mathrm{SO}_{4}^{2-}$ responses contributes to the $\mathrm{RF}$ and GWP differences seen among regions: $0.81 \mathrm{ppbv} \mathrm{CH}_{4}$ $\left(\mathrm{TgC}_{\mathrm{yr}}^{-1}\right)^{-1}, 0.073 \mathrm{Tg} \mathrm{O}_{3}\left(\mathrm{TgC} \mathrm{yr}^{-1}\right)^{-1}$, and $0.33 \mathrm{Gg}$ $\mathrm{SO}_{4}^{2-}\left(\mathrm{TgC} \mathrm{yr}^{-1}\right)^{-1}$ for the global reduction, and 0.40 to $1.61 \mathrm{ppbv}^{\mathrm{CH}_{4}}\left(\mathrm{Tg} \mathrm{Cyr}^{-1}\right)^{-1},-0.008$ to $0.101 \mathrm{Tg} \mathrm{O} \mathrm{O}_{3}$ $\left(\mathrm{TgC} \mathrm{yr}^{-1}\right)^{-1}$, and -0.21 to $1.01 \mathrm{Gg} \mathrm{SO}_{4}^{2-}\left(\mathrm{TgC} \mathrm{yr}^{-1}\right)^{-1}$ among the 10 regions. Several regions with high GWPs are low- $\mathrm{NO}_{\mathrm{x}}$ regions (AF and $\mathrm{AU}$ ), which have stronger $\mathrm{CH}_{4}$ sensitivities to NMVOC reductions, and weak increases or decreases in $\mathrm{SO}_{4}^{2-}$.

Anthropogenic NMVOC emissions overall contribute $\sim 5.1 \%$ (1.9 ppbv) to global annual average steady-state surface $\mathrm{O}_{3}$, by doubling the change from the $50 \%$ global NMVOC reduction $(-0.67 \mathrm{ppbv})$ and scaling for biomass burning emissions. Some regional reductions contribute importantly to surface $\mathrm{O}_{3}$ in other regions, such as $\mathrm{EA}, \mathrm{ME}$, and EU, which impact US surface $\mathrm{O}_{3}$ by $43 \%, 34 \%$, and $34 \%$, respectively, of that from NA emissions. NMVOC emission reductions mostly have a greater impact on downwind $\mathrm{O}_{3}$ production than the formation and export of $\mathrm{O}_{3}$ from each source region. Long-term surface $\mathrm{O}_{3}$ changes $\left(\right.$ via $\left.\mathrm{CH}_{4}\right) \mathrm{im}$ pact air quality globally, and for most regions add 5-18\% to short-term changes.

In this study, the air quality and RF impacts are derived from one CTM and RTM, which limits our ability to capture a more complete range of $\mathrm{CH}_{4}, \mathrm{O}_{3}$, aerosols, and $\mathrm{RF}$ responses, as a model ensemble would. Previous studies have shown a large model spread in $\mathrm{CH}_{4}, \mathrm{O}_{3}$, and $\mathrm{SO}_{4}^{2-}$ responses to regional NMVOC emissions (Collins et al., 2002; Fiore et al., 2009; Fry et al., 2012). Future work could examine the emissions inventories of NMVOCs and other species, as they are fairly uncertain among models (Berntsen et al., 2005).

Other limitations include only accounting for $\mathrm{CH}_{4}, \mathrm{O}_{3}$, and $\mathrm{SO}_{4}^{2-}$ (direct effect only) in our net RF and GWP estimates, which may affect the magnitude of our estimates and variability among regions. Forcing mechanisms not accounted for include $\mathrm{NO}_{3}^{-}$, SOA, stratospheric $\mathrm{O}_{3}$, water vapor, the carbon cycle (via $\mathrm{O}_{3}$ and nitrogen deposition), the indirect effects of aerosols, and the internal mixing of aerosols. Future research could include these additional forcings and their uncertainty. The contribution of anthropogenic NMVOCs to SOA, in particular, is fairly uncertain, and often underpredicted by models (Volkamer et al., 2006). The influence of climate feedbacks on chemistry and future changes in emissions also may alter the air quality and RF sensitivities estimated here for present-day emissions. In addition, while we focus on the sensitivity of air quality and RF to NMVOC emissions, which is useful in determining the GWP of NMVOCs, emission control measures would likely affect co-emitted species. Our results can be combined with those for co-emitted pollutants to evaluate the net 
effect of measures affecting multiple pollutants. Full climate responses also could be evaluated, as in Shindell and Faluvegi (2009).

These findings of high variability in GWPs among regions for NMVOCs contrast with our earlier findings for $\mathrm{CO}$, with little variability in GWPs among source regions (Fry et al., 2013). While it would be possible to include CO in multi-gas emissions trading schemes using a single GWP, with little error, using a single GWP for NMVOCs would cause significant error. Instead, international climate agreements could consider including NMVOCs in multi-gas emissions trading schemes using GWPs that are specific to each region. Although NMVOCs are a small climate forcing agent, this study motivates reductions in NMVOC emissions as part of future coordinated policies addressing air quality and climate change (Rypdal et al., 2005, 2009; Jackson et al., 2009; Shindell et al., 2012; Fry et al., 2013).

\section{Supplementary material related to this article is available online at http://www.atmos-chem-phys.net/14/ 523/2014/acp-14-523-2014-supplement.pdf.}

Acknowledgements. This research has been funded by the US EPA under the Science to Achieve Results (STAR) Graduate Fellowship Program (M. Fry), and by the US EPA Office of Air Quality Planning and Standards. EPA has not officially endorsed this report, and the views expressed herein may not reflect the views of EPA. We acknowledge contributions from V. Naik (UCAR/NOAA GFDL) to the methodology and development of the manuscript. We also thank L. Emmons (UCAR) for observation comparison tools, L. Emmons and S. Walters (UCAR) for MOZART-4 guidance, and W. J. Collins (University of Reading) for GWP calculation methodology.

Edited by: E. Gerasopoulos

\section{References}

Barth, M. C., Rasch, P. J., Kiehl, J. T., Benkovitz, C. M., and Schwartz, S. E.: Sulfur chemistry in the National Center for Atmospheric Research Community Climate Model: Description, evaluation, features, and sensitivity to aqueous chemistry, J. Geophys. Res., 105, 1387-1415, 2000.

Bauer, S. E., Koch, D., Unger, N., Metzger, S. M., Shindell, D. T., and Streets, D. G.: Nitrate aerosols today and in 2030: a global simulation including aerosols and tropospheric ozone, Atmos. Chem. Phys., 7, 5043-5059, doi:10.5194/acp-7-5043-2007, 2007.

Berntsen, T. K., Fuglestvedt, J. S., Joshi, M. M., Shine, K. P., Stuber, N., Ponater, M., Sausen, R., Hauglustaine, D. A., and Li, L.: Response of climate to regional emissions of ozone precursors: sensitivities and warming potentials, Tellus, 57B, 283-304, doi:10.1111/j.1600-0889.2005.00152.x, 2005.

Berntsen, T. K., Fuglestvedt, J., Myhre, G., Stordal, F., and Bergle, T. F.: Abatement of greenhouse gases: Does location matter?,
Climatic Change, 74, 377-411, doi:10.1007/s10584-006-04334, 2006.

Carlton, A. G., Wiedinmyer, C., and Kroll, J. H.: A review of Secondary Organic Aerosol (SOA) formation from isoprene, Atmos. Chem. Phys., 9, 4987-5005, doi:10.5194/acp-9-4987-2009, 2009.

Chung, S. and Seinfeld, J.: Global distribution and climate forcing of carbonaceous aerosols, J. Geophys. Res., 107, 4407, doi:10.1029/2001JD001397, 2002.

Cionni, I., Eyring, V., Lamarque, J.-F., Randel, W. J., Stevenson, D. S., Wu, F., Bodeker, G. E., Shepherd, T. G., Shindell, D. T., and Waugh, D. W.: Ozone database in support of CMIP5 simulations: results and corresponding radiative forcing, Atmos. Chem. Phys., 11, 11267-11292, doi:10.5194/acp-11-11267-2011, 2011.

Collins, W. J., Derwent, R. G., Johnson, C. E., and Stevenson, D. S.: The oxidation of organic compounds in the troposphere and their global warming potentials, Climatic Change, 52, 453-479, doi:10.1023/A:1014221225434, 2002.

Collins, W. J., Fry, M. M., Yu, H., Fuglestvedt, J. S., Shindell, D. T., and West, J. J.: Global and regional temperature-change potentials for near-term climate forcers, Atmos. Chem. Phys., 13, 2471-2485, doi:10.5194/acp-13-2471-2013, 2013.

Daniel, J. S. and Solomon, S.: On the climate forcing of carbon monoxide, J. Geophys. Res., 103, 13249-13260, doi:10.1029/98JD00822, 1998.

Ehhalt, D., Prather, M., Dentener, F., Derwent, R., Dlugokencky, E., Holland, E., Isaksen, I., Katima, J., Kirchhoff, V., Matson, P., Midgley, P., and Wang, M.: Atmospheric chemistry and greenhouse gases, in: Climate Change 2001: The Scientific Basis, Contribution of Working Group I to the Third Assessment Report of the Intergovernmental Panel on Climate Change, edited by: Houghton, J. T., Ding, Y., Griggs, D. J., Noguer, M., van der Linden, P. J., Dai, X., Maskell, K., and Johnson, C. A., Cambridge University Press, Cambridge, UK, 257-259, 2001.

Emmons, L. K., Walters, S., Hess, P. G., Lamarque, J.-F., Pfister, G. G., Fillmore, D., Granier, C., Guenther, A., Kinnison, D., Laepple, T., Orlando, J., Tie, X., Tyndall, G., Wiedinmyer, C., Baughcum, S. L., and Kloster, S.: Description and evaluation of the Model for Ozone and Related chemical Tracers, version 4 (MOZART-4), Geosci. Model Dev., 3, 43-67, doi:10.5194/gmd3-43-2010, 2010.

Fiore, A. M., Jacob, D. J., Field, B. D., Streets, D. G., Fernandes, S. D., and Jang, C.: Linking ozone pollution and climate change: The case for controlling methane, Geophys. Res. Lett., 29, 1919, doi:10.1029/2002GL015601, 2002.

Fiore, A. M., Dentener, F. J., Wild, O., Cuvelier, C., Schultz, M. G., Hess, P., Textor, C., Schulz, M., Doherty, R. M., Horowitz, L. W., MacKenzie, I. A., Sanderson, M. G., Shindell, D. T., Stevenson, D. S., Szopa, S., Van Dingenen, R., Zeng, G., Atherton, C., Bergmann, D., Bey, I., Carmichael, G., Collins, W. J., Duncan, B. N., Faluvegi, G., Folberth, G., Gauss, M., Gong, S., Hauglustaine, D., Holloway, T., Isaksen, I. S. A., Jacob, D. J., Jonson, J. E., Kaminski, J. W., Keating, T. J., Lupu, A., Marmer, E., Montanaro, V., Park, R. J., Pitari, G., Pringle, K. J., Pyle, J. A., Schroeder, S., Vivanco, M. G., Wind, P., Wojcik, G., Wu, S., and Zuber, A.: Multimodel estimates of intercontinental sourcereceptor relationships for ozone pollution, J. Geophys. Res., 114, D04301, doi:10.1029/2008JD010816, 2009. 
Forster, P., Ramaswamy, V., Artaxo, P., Berntsen, T., Betts, R., Fahey, D. W., Haywood, J., Lean, J., Lowe, D. C., Myhre, G., Nganga, J., Prinn, R., Raga, G., Schulz, M., and Van Dorland, R.: Changes in atmospheric constituents and in radiative forcing, in: Climate Change 2007: The Physical Science Basis. Contribution of Working Group I to the Fourth Assessment Report of the Intergovernmental Panel on Climate Change, edited by: Solomon, S., Qin, D., Manning, M., Chen, Z., Marquis, M., Averyt, K. B., Tignor, M., and Miller, H. L., Cambridge Univ. Press, Cambridge, UK, 129-234, 2007.

Fry, M. M., Naik, V., West, J. J., Schwarzkopf, M. D., Fiore, A. M., Collins, W. J., Dentener, F. J., Shindell, D. T., Atherton, C., Bergmann, D., Duncan, B. N., Hess, P., MacKenzie, I. A., Marmer, E., Schultz, M. G., Szopa, S., Wild, O., and Zeng, G.: The influence of ozone precursor emissions from four world regions on tropospheric composition and radiative climate forcing, J. Geophys. Res., 117, D07306, doi:10.1029/2011JD017134, 2012.

Fry, M. M., Schwarzkopf, M. D., Adelman, Z., Naik, V., Collins, W. J., and West, J. J.: Net radiative forcing and air quality responses to regional $\mathrm{CO}$ emission reductions, Atmos. Chem. Phys., 13, 5381-5399, doi:10.5194/acp-13-5381-2013, 2013.

Fuglestvedt, J. S., Isaksen, I. S. A., and Wang, W.-C.: Estimates of indirect global warming potentials for $\mathrm{CH}_{4}, \mathrm{CO}$, and $\mathrm{NO}_{\mathrm{x}}$. Clim. Change, 34, 405-437, 1996.

GFDL Global Atmospheric Model Development Team (GAMDT): The new GFDL global atmosphere and land model AM2-LM2: Evaluation with prescribed SST simulations, J. Clim., 17, 46414673, 2004.

Guenther, A., Karl, T., Harley, P., Wiedinmyer, C., Palmer, P. I., and Geron, C.: Estimates of global terrestrial isoprene emissions using MEGAN (Model of Emissions of Gases and Aerosols from Nature), Atmos. Chem. Phys., 6, 3181-3210, doi:10.5194/acp-63181-2006, 2006.

Hoyle, C. R., Myhre, G., Berntsen, T. K., and Isaksen, I. S. A.: Anthropogenic influence on SOA and the resulting radiative forcing, Atmos. Chem. Phys., 9, 2715-2728, doi:10.5194/acp-9-27152009, 2009.

Ito, A., Sillman, S., and Penner, J. E.: Effects of additional nonmethane volatile organic compounds, organic nitrates, and direct emissions of oxygenated organic species on global tropospheric chemistry, J. Geophys. Res., 112, D06309, doi:10.1029/2005JD006556, 2007.

Jackson, S. C.: Parallel Pursuit of Near-term and Longterm Climate Mitigation, Science, 326, 5952, 526-527, doi:10.1126/science.1177042, 2009.

Jacob, D. J.: Introduction to Atmospheric Chemistry, Princeton University Press, Princeton, NJ, USA, 52-53, 1999.

Lamarque, J.-F., Kiehl, J. T., Hess, P. G., Collins, W. D., Emmons, L. K., Ginoux, P., Luo, C., and Tie, X. X.: Response of a coupled chemistry-climate model to changes in aerosol emissions: Global impact on the hydrological cycle and the tropospheric burdens of $\mathrm{OH}$, ozone, and $\mathrm{NO}_{\mathrm{x}}$, Geophys. Res. Lett., 32, L16809, doi:10.1029/2005GL023419, 2005.

Leibensperger, E. M., Mickley, L. J., Jacob, D. J., and Barrett, S. R. H.: Intercontinental influence of $\mathrm{NO}_{\mathrm{x}}$ and $\mathrm{CO}$ emissions on particulate matter air quality, Atmos Environ., 45, 3318-3324, doi:10.1016/j.atmosenv.2011.02.023, 2011.
Liu, X.-H., Zhang, Y., Xing, J., Zhang, Q., Wang, K., Streets, D. G., Jang, C., Wang, W.-X., and Hao, J.-M.: Understanding of regional air pollution over China using CMAQ, part II. Process analysis and sensitivity of ozone and particulate matter to precursor emissions, Atmos. Environ., 44, 3719-3727, 2010.

Meinshausen, M., Smith, S. J., Calvin, K. V., Daniel, J. S., Kainuma, M. L. T., Lamarque, J.-F., Matsumoto, K., Montzka, S. A., Raper, S. C. B., Riahi, K., Thomson, A. M., Velders, G. J. M., and van Vuuren, D.: The RCP Greenhouse Gas Concentrations and their Extension from 1765 to 2300, Climatic Change (Special Issue), 109, 213-241, doi:10.1007/s10584-011-0156-z, 2011.

Metzger, S., Dentener, F., Pandis, S., and Lelieveld, J.: Gas/aerosol partitioning: 1. A computationally efficient model, J. Geophys. Res., 107, 4312, doi:10.1029/2001JD001102, 2002.

Naik, V., Mauzerall, D., Horowitz, L., Schwarzkopf, M. D., Ramaswamy, V., and Oppenheimer, M.: Net radiative forcing due to changes in regional emissions of tropospheric ozone precursors, J. Geophys. Res., 110, D24306, doi:10.1029/2005JD005908, 2005.

Naik, V., Mauzerall, D. L., Horowitz, L. W., Schwarzkopf, M. D., Ramaswamy, V., and Oppenheimer, M.: On the sensitivity of radiative forcing from biomass burning aerosols and ozone to emission location, Geophys. Res. Lett., 34, L03818, doi:10.1029/2006GL028149, 2007.

Prather, M., Ehhalt, D., Dentener, F., Derwent, R. G., Dlugokencky, E., Holland, E., Isaksen, I. S. A., Katima, J., Kirchhoff, V., Matson, P., Midgley, P. M., and Wang, M.: Climate Change 2001: The Scientific Basis, Atmospheric Chemistry and Greenhouse Gases, Chap. 4, Cambridge Univ. Press, New York, USA, 239287, 2001.

Prather, M. J.: Time scales in atmospheric chemistry: Theory, GWPs for $\mathrm{CH}_{4}$ and $\mathrm{CO}$, and runaway growth, Geophys. Res. Lett., 23, 2597-2600, doi:10.1029/96GL02371, 1996.

Riahi, K., Gruebler, A., and Nakicenovic, N.: Scenarios of long-term socio-economic and environmental development under climate stabilization, Technological Forecasting and Social Change, 74, 7, 887-935, 2007.

Riahi, K., Rao, S., Krey, V., Cho, C., Chirkov, V., Fischer, G., Kindermann, G., Nakicenovic, N., and Rafaj, P.: RCP 8.5 - A scenario of comparatively high greenhouse gas emissions, Climatic Change, 109, 33-57, doi:10.1007/s10584-011-0149-y, 2011.

Rienecker, M. M., Suarez, M. J., Todling, R., Bacmeister, J., Takacs, L., Liu, H.-C., Gu, W., Sienkiewicz, M., Koster, R. D., Gelaro, R., Stajner, I., and Nielsen, J. E.: The GEOS-5 Data Assimilation System - Documentation of versions 5.0.1, 5.1.0, and 5.2.0, NASA Tech. Memo., NASA/TM-2008-104606, vol. 27, 118 pp., 2008.

Rypdal, K., Berntsen, T., Fuglestvedt, J. S., Aunan, K., Torvanger, A., Stordal, F., Pacyna, J. M., and Nygaard, L. P.: Tropospheric ozone and aerosols in climate agreements: scientific and political challenges, Environ. Sci. Policy, 8, 29-43, doi:10.1016/j.envsci.2004.09.003, 2005.

Rypdal, K., Rive, N., Berntsen, T., Fagerli, H., Klimont, Z., Mideksa, T. K., and Fuglestvedt, J. S.: Climate and air qualitydriven scenarios of ozone and aerosol precursor abatement, Environ. Sci. Policy, 12, 855-869, doi:10.1016/j.envsci.2009.08.002, 2009.

Saikawa, E., Naik, V., Horowitz, L. W., Liu, J. F., and Mauzerall, D. L.: Present and potential future contributions of sulfate, black and 
organic carbon aerosols from China to global air quality, premature mortality and radiative forcing, Atmos. Environ., 43, 28142822, doi:10.1016/j.atmosenv.2009.02.017, 2009.

Schwarzkopf, M. D. and Ramaswamy, V.: Radiative effects of $\mathrm{CH}_{4}, \mathrm{~N}_{2} \mathrm{O}$, halocarbons and the foreign-broadened $\mathrm{H}_{2} \mathrm{O}$ continuum: A GCM experiment, J. Geophys. Res., 104, 9467-9488, doi:10.1029/1999JD900003, 1999.

Shindell, D. and Faluvegi, G.: Climate response to regional radiative forcing during the twentieth century, Nature Geosci., 2, 294-300, doi:10.1038/NGEO473, 2009.

Shindell, D., Kuylenstierna, J. C. I., Vignati, E., van Dingenen, R., Amann, M., Klimont, Z., Anenberg, S. C., Muller, N., JanssensMaenhout, G., Raes, F., Schwartz, J., Faluvegi, G., Pozzoli, L., Kupiainen, K., Höglund-Isaksson, L., Emberson, L., Streets, D., Ramanathan, V., Hicks, K., Oanh, N. T. K., Milly, G., Williams, M., Demkine, V., and Fowler, D.: Simultaneously mitigating near-term climate change and improving human health and food security. Science, 335, 183-189, doi:10.1126/science.1210026, 2012

Shindell, D. T., Faluvegi, G., Bell, N., and Schmidt, G. A.: An emissions-based view of climate forcing by methane and tropospheric ozone, Geophys. Res. Lett., 32, L04803, doi:10.1029/2004GL021900, 2005.

Shindell, D. T., Faluvegi, G., Koch, D. M., Schmidt, G. A., Unger, N., and Bauer, S. E.: Improved attribution of climate forcing to emissions, Science, 326, 716-718, doi:10.1126/science.1174760, 2009.

Shindell, D. T., Lamarque, J.-F., Schulz, M., Flanner, M., Jiao, C., Chin, M., Young, P. J., Lee, Y. H., Rotstayn, L., Mahowald, N., Milly, G., Faluvegi, G., Balkanski, Y., Collins, W. J., Conley, A. J., Dalsoren, S., Easter, R., Ghan, S., Horowitz, L., Liu, X., Myhre, G., Nagashima, T., Naik, V., Rumbold, S. T., Skeie, R., Sudo, K., Szopa, S., Takemura, T., Voulgarakis, A., Yoon, J.-H., and Lo, F.: Radiative forcing in the ACCMIP historical and future climate simulations, Atmos. Chem. Phys., 13, 2939-2974, doi:10.5194/acp-13-2939-2013, 2013.

Sillman, S., He, D., Cardelino, C., and Imhoff, R. E.: The use of photochemical indicators to evaluate ozone-NOx-hydrocarbon sensitivity: Case studies from Atlanta, New York, and Los Angeles, J. Air Waste Manage. Assoc., 47, 1030-1040, 1997.

Søvde, O. A., Hoyle, C. R., Myhre, G., and Isaksen, I. S. A.: The $\mathrm{HNO}_{3}$ forming branch of the $\mathrm{HO}_{2}+\mathrm{NO}$ reaction: pre-industrialto-present trends in atmospheric species and radiative forcings, Atmos. Chem. Phys., 11, 8929-8943, doi:10.5194/acpd-118929-2011, 2011.

Stevenson, D. S., Dentener, F. J., Schultz, M. G., Ellingsen, K., van Noije, T. P. C., Wild, O., Zeng, G., Amann, M., Atherton, C. S., Bell, N., Bergmann, D. J., Bey, I., Butler, T., Cofala, J., Collins, W. J., Derwent, R. G., Doherty, R. M., Drevet, J., Eskes, H. J., Fiore, A. M., Gauss, M., Hauglustaine, D. A., Horowitz, L. W., Isaksen, I. S. A., Krol, M. C., Lamarque, J.-F., Lawrence, M. G., Montanaro, V., Müller, J.-F., Pitari, G., Prather, M. J., Pyle, J. A., Rast, S., Rodriguez, J. M., Sanderson, M. G., Savage, N. H., Shindell, D. T., Strahan, S. E., Sudo, K., and Szopa, S.: Multimodel ensemble simulations of present-day and near-future tropospheric ozone, J. Geophys. Res., 111, D08301, doi:10.1029/2005JD006338, 2006.
Stevenson, D. S., Young, P. J., Naik, V., Lamarque, J.-F., Shindell, D. T., Voulgarakis, A., Skeie, R. B., Dalsoren, S. B., Myhre, G., Berntsen, T. K., Folberth, G. A., Rumbold, S. T., Collins, W. J., MacKenzie, I. A., Doherty, R. M., Zeng, G., van Noije, T. P. C., Strunk, A., Bergmann, D., Cameron-Smith, P., Plummer, D. A., Strode, S. A., Horowitz, L., Lee, Y. H., Szopa, S., Sudo, K., Nagashima, T., Josse, B., Cionni, I., Righi, M., Eyring, V., Conley, A., Bowman, K. W., Wild, O., and Archibald, A.: Tropospheric ozone changes, radiative forcing and attribution to emissions in the Atmospheric Chemistry and Climate Model Intercomparison Project (ACCMIP), Atmos. Chem. Phys., 13, 3063-3085, doi:10.5194/acp-13-3063-2013, 2013.

Unger, N., Shindell, D. T., Koch, D. M., and Streets, D. G.: Cross influences of ozone and sulfate precursor emissions changes on air quality and climate, Proc. Natl. Acad. Sci., 103, 12, 4377 4380, doi:10.1073/pnas.0508769103, 2006.

Volkamer, R., Jimenez, J. L., San Martini, F., Dzepina, K., Zhang, Q., Salcedo, D., Molina, L. T., Worsnop, D. R., and Molina, M. J.: Secondary organic aerosol formation from anthropogenic air pollution: Rapid and higher than expected, Geophys. Res. Lett., 33, L17811, doi:10.1029/2006GL026899, 2006.

West, J. J., Fiore, A. M., Naik, V., Horowitz, L. W., Schwarzkopf, M. D., and Mauzerall, D. L.: Ozone air quality and radiative forcing consequences of changes in ozone precursor emissions, Geophys. Res. Lett., 34, L06806, doi:10.1029/2006GL029173, 2007.

West, J. J., Naik, V., Horowitz, L. W., and Fiore, A. M.: Effect of regional precursor emission controls on long-range ozone transport - Part 1: Short-term changes in ozone air quality, Atmos. Chem. Phys., 9, 6077-6093, doi:10.5194/acp-9-6077-2009, 2009a.

West, J. J., Naik, V., Horowitz, L. W., and Fiore, A. M.: Effect of regional precursor emission controls on long-range ozone transport - Part 2: Steady-state changes in ozone air quality and impacts on human mortality, Atmos. Chem. Phys., 9, 6095-6107, doi:10.5194/acp-9-6095-2009, 2009b.

Wild, O., Prather, M. J., and Akimoto, H.: Indirect long-term global radiative cooling from $\mathrm{NO}_{\mathrm{x}}$ emissions, Geophys. Res. Lett., 28, 1719-1722, doi:10.1029/2000GL012573, 2001.

World Meteorological Organization (WMO): WMO Greenhouse Gas Bulletin: The State of Greenhouse Gases in the Atmosphere using Global Observations through 2005, Bulletin No. 1: March 2006, 2006. 